О. Є. Січкоріз, Т. І. Пупін, Л. Ю. Мінько, Т. С. Колач

Львівський національний медичний університет імені Данила Галицького

\title{
ІНТЕГРАЦІЯ ДИСТАНЦИЙНОЇ ФОРМИ В НАВЧАЛЬНИЙ ПРОЦЕС НА ПІСЛЯДИПЛОМНОМУ ЕТАПІ ПІДГОТОВКИ ЛІКАРІВ-ІНТЕРНІВ ДО СКЛАДАННЯ ЛІЦЕНЗІЙНОГО ІСПИТУ “КРОК-З. СТОМАТОЛОГІЯ”: РЕАЛІЇ ТА ПЕРСПЕКТИВИ
}

\author{
O. E. Sichkoris, T. I. Pupin, L. Yu. Minko, T. S. Kolach \\ Danylo Halytskyi Lviv National Medical University
}
INTEGRATION OF THE DISTANCE E-LEARNING IN THE EDUCATIONAL PROCESS AT THE POSTGRADUATE EDUCATION DURING PREPARATION TO THE EXAM PASSING OF LICENSED EXAM “KROK-3” “DENTISTRY": REALITY AND PROSPECTS

\begin{abstract}
Мета роботи - впровадження дистанційної форми в навчальний процес лікарів-інтернів як складової підготовки до складання ліцензійного іспиту “Крок-З. Стоматологія”, оцінка переваг та недоліків.

Основна частина. До курсу ДН “КРОК-3. Стоматологія” на програмній платформі “Модус” [http://misa.meduniv.lviv.ua/] залучено 145 лікарів-інтернів першого року навчання, котрі проходили очну частину інтернатури на ФПДО ЛНМУ імені Данила Галицького. Аналіз результатів трьох блоків вказує на зниження середнього відсотка успішності на фоні підвищення середньої кількості пропущених претестувань в Блоках II та III порівняно з Блоком I. Так, на кінець Блоку II ДН середній відсоток успішності знизився на 9,71 \%, на кінець Блоку III - на 32,58 \% порівняно з Блоком I, при зростанні середньої кількості пропущених претестувань у Блоці II - у майже 2,5 раза та у Блоці III - у 3,17 раза порівняно з підготовкою на очному циклі інтернатури. Встановлено вірогідний зворотний кореляційний зв’язок між середньою кількістю пропущених претестувань та результатами “KPOK-3” ( $\mathrm{r}=-0,14$ при $\mathrm{p}<0,05)$ і прямий кореляційний зв’язок між середнім відсотком підготовки за три блоки ДН та результатами “КРОК-3” (r=0,23 при p<0,05). Аналіз проведених трьох блоків ДН лікарів-інтернів, що склали та не склали “КРОК-3. Стоматологія”, вказує на достовірну різницю між показниками як середньої кількості пропущених тестових тренувань - нижче в 1,2 раза в осіб, що склали іспит (p<0,01), порівняно з тими, хто не склав, так і вищого в 1,32 раза середнього відсотка успішності на тестових тренуваннях відповідно ( $<<0,0001)$.

Висновки. Запровадження ДН дозволило лікарям-інтернам проходити претестування в зручний для них час з обов’язковим контролем хронометражу часу та можливістю ревізії власних помилок; викладачам здійснювати контроль за підготовкою до “КРОК-3” дистанційно й забезпечити безперервність підготовки до ліцензійного іспиту. Водночас, згідно з аналізом проведеного дослідження, ДН не може бути самостійною формою в підготовці до “КРОК-3. Стоматологія”, оскільки вимагає високого рівня самодисципліни лікаря-інтерна, проте як інтегрований курс дозволяє виявити та сформувати групу ризику на підставі аналізу даних середньої кількості пропущених претестувань та середнього відсотка успішності, особливо на етапі заочної форми інтернатури.
\end{abstract}

Ключові слова: дистанційне навчання; первинна спеціалізація (інтернатура).

The aim of the work - implementation of the distance form in the educational process of interns as a part of the preparation for the licensing exam "Krok-3. Dentistry", an assessment of the advantages and disadvantages.

The main body. It was analyzed the results of 1451 st year students of postgraduate faculty of Danylo Halytskyi Lviv National Medical University, who had the tests "Krok-3. Dentistry". All testing was made using the "Modus" platform [http://misa.meduniv.lviv.ua/].

Analysis of three blocks of testing demonstrated decreasing of the average percent of successful passing of exam on the background of increasing of quantity of missed pre-testing classes in Block II and Block III compared to Block I. So, we observed the dropping of average rate of success by $9.71 \%$ at the end of Block II; and by $32.58 \%$ - at Block III. Rising of missed pre-tests was increased by 2.5-fold for Block II and 3.17-fold for Block III. It is a significant reverse correlation for missing pre-tests and results of "Krok-3" $(r=-0.14, p<0.05)$ and direct correlation among average success rate during all three Blocks and "Krok-3" results $(r=0.23, p<0.05)$.

Analyzing the average success rate of "Krok-3. Dentistry" showed significant difference among indices of missed pre-tests (it was lower by 1.2-fold for those who did pass the exam $(\mathrm{p}<0.01)$ with their significant higher average percentage of success rate - by 1.32 fold, $(\mathrm{p}<0.0001)$.

Conclusions. Implementation of the State Program allows doing tests at the convenient time with obligatory timing control and a possibility to revise its own mistakes. It allows performing of distant supervision for the process of preparing to "Krok-3" and maintains

(ㄱ О. Є. Січкоріз, Т. І. Пупін, Л. Ю. Мінько, Т. С. Колач 
its continuity. At the same time, the State Program could not be the self-preparing independent form of study "Krok", because it requires strict discipline for doctor of the internship. But, as an integrated course it permits to assess the group of risks analyzing the data of missed pre-tests and average success rate, especially during the correspondence internship form.

Key words: e-learning education; primary specialization (internship).

Вступ. Метою Державної програми з підготовки спеціалістів є підвищення якості, доступності й конкурентоспроможності національної освіти та науки на світовому ринку праці й освітянських послуг, а також створення умов для безперервного навчання протягом усього життя. Тому пріоритетним напрямком діяльності ЛНМУ імені Данила Галицького є реалізація вимог законів "Про вищу освіту" та "Про наукову та науково-технічну діяльність", нового Закону України “Про освіту” (від 05.09.2017 року) [1], де однією з головних засад державної політики і принципом освітньої діяльності визначено забезпечення якості освіти та якості освітньої діяльності. В Законі України “Про основні засади розвитку інформаційного суспільства в Україні на 2007-2015 роки” підкреслюється необхідність забезпечення комп’ютерної та інформаційної грамотності населення і важливість створення системи освіти, орієнтованої на використання новітніх інформаційних технологій [2].

Широке впровадження в систему вищої освіти сучасних комп’ютерних та телекомунікаційних технологій створює умови для розвитку дистанційних форм навчання. Згідно з діючим Положенням про дистанційне навчання, що було затверджене наказом Міністерства освіти і науки України від 25.04.2013 року № 466 [3], дистанційне навчання являє собою нову організацію освіти, що грунтується на використанні як кращих традиційних методів отримання знань, так і нових інформаційних та телекомунікаційних технологій, а також базується на принципах самоосвіти.

Тому інтеграція дистанційної освіти в навчальний процес на післядипломному навчанні, особливо на етапі первинної спеціалізації (інтернатури), є необхідною умовою та вимогою сьогодення.

Мета роботи - впровадження дистанційної форми в навчальний процес лікарів-інтернів як складової підготовки до складання ліцензійного іспиту “Крок-3. Стоматологія”, оцінка переваг та недоліків.

Основна частина. Здійснення підготовки лікарів-інтернів до ліцензійного іспиту “КРОК-3. Стоматологія” на ФПДО ЛНМУ імені Данила Галицького грунтується на рекомендаціях Центру тестування при МОЗ України [4] та проводиться курсом, який розподілений на два блоки [5]. Перший блок здійснюють на кафедрах, які задіяні на первинній спеціалізації (інтернатурі) (очна частина) шляхом щоденних претестувань з аналітичним розбором складних тестових завдань після проведення претестування. Другий блок здійснюється деканатом шляхом створення буклетів, які складаються за довільним вибором завдань з бази даних Центру тестування МОЗ України. Таких претестувань деканат проводить 10 під час очної частини навчання в інтернатурі. Крім того, інтерни користуються буклетами Центру тестування МОЗ України, які після завершення іспиту залишаються в деканаті. 3 метою інтеграції дистанційної форми підготовки лікарів-інтернів, які складають іспит "КРОК-3. Стоматологія”, спільно з відділом інформатизації нашого університету розроблена та впроваджена програмна платформа “Модус" [http://misa.meduniv. lviv.ua/], технічне впровадження та інформаційна підтримка якої забезпечується кафедрою інформатики. Методичну роботу, щодо підготовки лікарівінтернів до складання ліцензійних іспитів "Крок-3. Стоматологія”, здійснюють викладачі профільних кафедр.

До дистанційної підготовки до “КРОК-3. Стоматологія” залучено 145 лікарів-інтернів першого року навчання, котрі проходили очну частину інтернатури на ФПДО ЛНМУ імені Данила Галицького. Тривалість курсу дистанційного навчання (ДН) здійснювалася протягом очного й заочного навчання та, у свою чергу, була поділена на три блоки. Блок I включав: реєстрацію на курс дистанційного навчання, навчальне заняття з "Навчання роботи з курсом” та “Курс підготовки до ліцензійного іспиту”. Даний блок здійснювався на очній частині навчання в інтернатурі, тривалістю 5 місяців i містив 5 тренувальних претестувань. Блок II: курс “Контрольних пре тестувань”- проводився під час заочної частини інтернатури на базах стажування. Тривалість - 7 місяців, всього 10 тренувальних претестувань. Блок III: курс "Контрольних претестувань”, який поєднувався з консультаціями на профільних кафедрах ФПДО, тривалість 1 місяць (12 тренувальних претестувань). Тренувальні претестування містили 200 питань, тривалість тесту 3 год 20 хв. Підсумком стало складання лікарями- 
інтернами “КРОК-3. Стоматологія”. Статистична обробка матеріалів проводилась за допомогою комп’ютерної програми Statistica 10.0.

Блок I: на етапі забезпечення контролю за підготовкою до ліцензійного іспиту “КРОК-3” було залучено ДН. На очному курсі було проведено 5 претестувань. Тест містив перелік питань буклетів попередніх років. Перевірка тестів здійснювалася дистанційно в двох режимах: автоматизовано i безпосередньо викладачем. До впровадження механізму ідентифікації учасників процесу ДН перші три претестування проводились у паперовій формі, тобто здійснювалися за очною формою. Наступні два претестування здійснювали на платформі ДН у ЛНМУ імені Данила Галицького. Після Блоку I визначено якісні та кількісні результати інтеграції ДН в ЛНМУ. До якісних відносимо: запровадження дистанційного навчання дозволило лікарямінтернам проходити претестування в зручний для них час з обов'язковим контролем хронометражу часу та можливістю перевірки власних помилок; викладачам здійснювати контроль за підготовкою до “КРОК-3”, що дозволило вивільнити час на забезпечення практичних компетенцій у підготовці лікарів-інтернів, на очній частині інтернатури. До кількісних характеристик після проведення Блоку I відносять: середній відсоток успішності лікарів-інтернів, які здійснили підготовку, становив

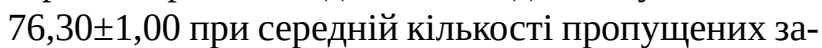

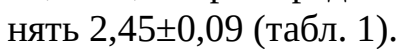

Таблиця 1. Загальні результати підготовки лікарів-інтернів, які складають “КРОК-З. Стоматологія”

\begin{tabular}{|l|c|c|c|}
\hline \multicolumn{1}{|c|}{ Блок навчання } & $\begin{array}{c}\text { Кількість } \\
\text { претестувань }\end{array}$ & $\begin{array}{c}\text { Середня кількість } \\
\text { пропущених занять } \\
(\mathrm{M} \pm \mathrm{m})\end{array}$ & $\begin{array}{c}\text { Середній відсоток } \\
\text { успішності } \\
(\mathrm{M} \pm \mathrm{m})\end{array}$ \\
\hline Блок I & $\mathrm{N}=5$ & $2,45 \pm 0,09$ & $76,30 \pm 1,00$ \\
\hline Блок II & $\mathrm{N}=10$ & $6,01 \pm 0,25$ & $68,89 \pm 2,61$ \\
\hline Блок III & $\mathrm{N}=12$ & $7,77 \pm 0,37$ & $51,44 \pm 3,48$ \\
\hline Всього & $\mathrm{N}=27$ & $16,23 \pm 0,57$ & $65,54 \pm 1,69$ \\
\hline
\end{tabular}

Блок II здійснювали на заочній частині інтернатури, середній відсоток успішності лікарів-інтернів стано-

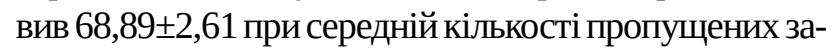

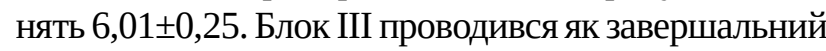
етап підготовки до “КРOK-3. Стоматологія” та містив змішані тестові завдання буклетів різних років,

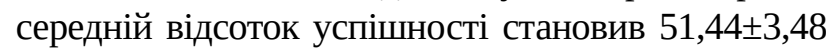
при середній кількості пропущених занять 7,77士0,37.

Аналіз результатів трьох блоків вказує на зниження середнього відсотка успішності на фоні підвищення середньої кількості пропущених претестувань в Блоках II та III порівняно з Блоком I. Це пов'язуємо зі зниженням рівня мотивації до навчання, адже загальновідомо, що дистанційна форма вимагає високого рівня самоорганізації від лікаря-інтерна [6, 7]. Так, на кінець Блоку II дистанційної підготовки середній відсоток успішності знизився на 9,71 \%, на кінець Блоку III - на 32,58 \% порівняно з Блоком I, при зростанні середньої кількості пропущених претестувань у Блоці II у майже 2,5 раза та у Блоці III - у 3,17 раза порівняно $з$ підготовкою на очному циклі інтернатури. Однак дозволило проводити підготовку дистанційно в режимі он-лайн та забезпечити безперервність тренувального процесу як під час очної частини навчання, так і тоді, коли лікарі-інтерни проходять заочну частину навчання на базах стажування.

Порівняння середнього відсотка підготовки до “КРОК-3. Стоматологія” з середнім відсотком результатів “КРОК-3” вказує на подібність. Так, 65,54 1,69 - середній результат підготовки та

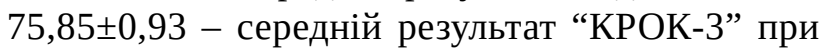
достовірності різниці $\mathrm{p}=0,053$. Тобто результати попередньої підготовки дозволяють спрогнозувати результат ліцензійного іспиту.

Обчислення кореляційних залежностей між середньою кількістю пропущених претестувань та результатами “КРОК-3”, а також між середнім відсотком результатів підготовки за три блоки та результатами “КРОК-3” виявило вірогідний зворотний кореляційний зв’язок між середньою кількістю пропущених претестувань та результатами “КРОК-3” (r= - 0,14 при p<0,05) і прямий кореляційний зв'язок між середнім відсотком підготовки за три блоки дистанційної підготовки та результатами “КРОK-3” ( $r=0,23$ при $\mathrm{p}<0,05)$.

Водночас проведено аналіз результатів лікарівінтернів, що склали успішно та не склали ліцензований іспит “КРОК-3”, з результатами підготовки (табл. 2). Так, після проведеного Блоку I, достовірної 
різниці середньої кількості пропущених тестових тренувань серед лікарів-інтернів, що склали й не склали “КРОК-3”, немає, проте середній відсоток успішності тестових тренувань на 10,19 \% вищий в осіб, що склали “КРОК-3” (p<0,01). Після закінчення Блоку II: середня кількість пропущених тестових тренувань на 24,13 \% менша у лікарів-інтернів, що склали “КРОК-3”, та тих, що не склали $(\mathrm{p}<0,01)$, середній відсоток успішності тестових тренувань майже в 1,5 раза вищий в осіб, що успішно склали “KPOK-3” (p<0,01). На кінець Блоку III отримали такі результати: середня кількість пропущених тестових тренувань в осіб, що склали “КРОK-3”, на 24,17 \% менша, ніж серед осіб, що не склали “KPOK-3” (p>0,05), середній відсоток успішності в 1,42 раза вищий у лікарів-інтернів, що склали “КРОК-3” ( $<<0,05)$. Згідно з даними, поданими в таблиці, встановлено достовірну різницю між середнім відсотком успішності та кількістю пропущених тестових тренувань у лікарів-інтернів, що склали та не склали “КРОК-3”, особливо це добре прослідковується у Блоках II та III дистанційного навчання.

Тому вважаємо, що саме дистанційна форма на етапі заочної інтернатури дозволить виявити лікарів-інтернів, що мають високу ймовірність не скласти “КРОK-3”.

Таблиця 2. Результати лікарів-інтернів на етапі підготовки, що склали та не склали “КРОК-3. Стоматологія"

\begin{tabular}{|c|c|c|c|c|}
\hline \multirow[b]{2}{*}{ Блок навчання } & \multicolumn{2}{|c|}{$\begin{array}{c}\text { Лікарі-інтерни, що склали } \\
\text { іспит }(\mathrm{N}=120) \\
\mathrm{M} \pm \mathrm{m}\end{array}$} & \multicolumn{2}{|c|}{$\begin{array}{c}\text { Лікарі-інтерни, що не склали } \\
\text { іспит }(\mathrm{N}=25) \\
\mathrm{M} \pm \mathrm{m}\end{array}$} \\
\hline & $\begin{array}{c}\text { середня кількість } \\
\text { пропущених } \\
\text { тестових } \\
\text { тренувань }\end{array}$ & $\begin{array}{c}\text { середній відсоток } \\
\text { успішності } \\
\text { тестових } \\
\text { тренувань } \\
\end{array}$ & $\begin{array}{c}\text { середня кількість } \\
\text { пропущених } \\
\text { тестових } \\
\text { тренувань } \\
\end{array}$ & $\begin{array}{c}\text { середній відсоток } \\
\text { успішності } \\
\text { тестових } \\
\text { тренувань }\end{array}$ \\
\hline Блок I & $2,41 \pm 0,09$ & $77,66 \pm 1,01 \# \#$ & $2,5 \pm 0,24$ & $69,75 \pm 2,90 \# \#$ \\
\hline Блок II & $5,69 \pm 0,28 * *$ & $73,28 \pm 2,56 \# \#$ & $7,5 \pm 0,56 * *$ & 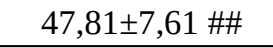 \\
\hline Блок III & $7,56 \pm 0,41$ & $54,23 \pm 3,83$ \# & $8,92 \pm 0,84$ & $38,02 \pm 7,87$ \# \\
\hline Блок I+II+III & $15,66 \pm 0,61 * *$ & 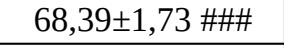 & $18,92 \pm 1,40 * *$ & 51,86士4,27 \#\#\# \\
\hline Середній результат “КРОК-3” & - & $79,81 \pm 0,39$ & - & $56,81 \pm 2,87$ \\
\hline
\end{tabular}

Примітка. Вірогідність різниці між показниками:

1. Лікарі-інтерни, що склали й не склали “КРОК-3”, та середньої кількості пропущених тестових тренувань: * р<0,05;

** $\mathrm{p}<0,01 ; * * * \mathrm{p}<0,0001$.

2. Лікарі-інтерни, що склали й не склали “КРОК-3”, та середнього відсотка успішності тестових тренувань: \#р<0,05; \#\# $\mathrm{p}<0,01 ; \ldots \# \mathrm{p}<0,0001$

Отже, аналіз проведених трьох блоків дистанційного навчання вказує на достовірну різницю між показниками як середньої кількості пропущених тестових тренувань - нижче в 1,2 раза в осіб, що склали іспит $(\mathrm{p}<0,01)$, порівняно $з$ тими, хто не склав, так і вищого в 1,32 раза середнього відсотка успішності на тестових тренуваннях відповідно ( $<$ 0,0001). Згідно з отриманими даними, важливою складовою успішної підготовки на дистанційному навчанні до “КРОК-3” є врахування не лише індивідуального відсотка успішності на тестових тренуваннях, а й кількості пропущених претестувань.

На рисунку 1 представлено різницю участі в дистанційній підготовці між даними групами інтернів. Так, середній відсоток виконаних претестувань серед лікарів-інтернів, що не склали “КРОК-3”, був в 1,5 раза нижчий, ніж в осіб, що успішно склали іспит.
Отримані результати після проведення трьох блоків дистанційної підготовки до “КРОК-3. Стоматологія” свідчать, що, незважаючи на всі переваги онлайн-навчання, середній відсоток складених претестувань серед лікарів-інтернів становив близько $(39,90 \pm 2,10) \%$. Тому вважаємо доцільним застосування підготовки до “KPOK-3” не у вигляді самостійного курсу, а у формі інтегрованої складової.

Висновки. Переваги дистанційного навчання: запровадження дистанційного навчання дозволило лікарям-інтернам проходити претестування в зручний для них час з обов'язковим контролем хронометражу часу та можливістю перевірки власних помилок; викладачам здійснювати контроль за підготовкою до “КРОК-3”, що дозволило вивільнити час на забезпечення практичних компетенцій у підготовці лікарів-інтернів, як на очній, так 


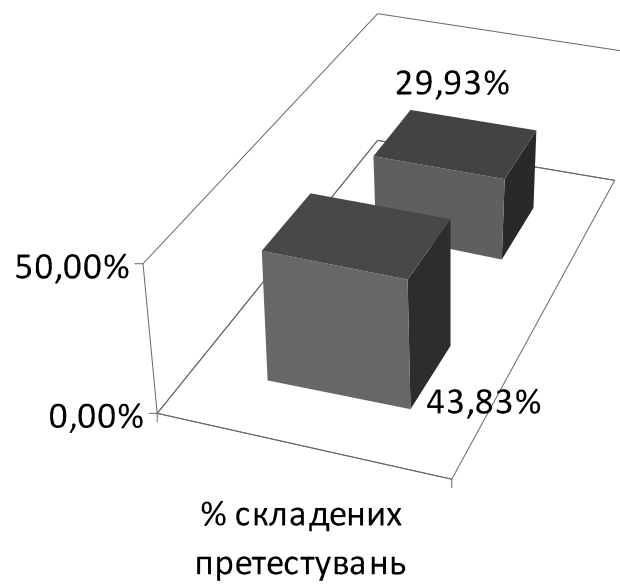

Лікарі-інтерни, що склали КРОК-3

Лікарі-інтерни, що не склали KPOK-3

Рис. 1. Відсоток складених претестувань серед лікарів-інтернів, які склали та не склали “КРОК-3”.

i на заочній частині інтернатури, та забезпечило безперервність підготовки до ліцензійного іспиту.

Недоліки дистанційного навчання: згідно з аналізом проведеного дослідження, дистанційне навчання не може бути самостійною формою в підготовці до “КРОК-З. Стоматологія”, оскільки вимагає висо-

\section{Список літератури}

1. Про освіту : Закон України від 05.09.2017 року № 2145-VIII [Електронний ресурс]. - Режим доступу : http://zakon0.rada.gov.ua/laws/show/2145-19.

2. Про Основні засади розвитку інформаційного суспільства в Україні на 2007-2015 роки : Закон України від 09.01.2007 року № 537-V [Електронний ресурс]. - Режим доступу : http://zakon5.rada.gov.ua/laws/show/537-16.

3. Положення про дистанційне навчання (затверджено наказом Міністерства освіти і науки України від 25.04.2013 року № 466) [Електронний ресурс]. Режим доступу : http://zakon4.rada.gov.ua/laws/show/ z0703-13\#n18.

4. Готуємось до іспиту / Центр тестування при MO3 України [Електронний ресурс]. - Режим доступу : https:// www.testcentr.org.ua/uk/ispyty/dokumenty-i-materialy/ ekzamenatsiini-buklety.

5. Факультет післядипломної освіти ЛНМУ імені Данила Галицького [Електронний ресурс]. - Режим досту-

\section{References}

1. Pro osvitu: Zakon Ukrainy vid 05.09.2017 roku № 2145-VIII [About education: Law of Ukraine dated September 5, 2017, No. 2145-VIII]. Retrieved from: http://zakon0. rada.gov.ua/laws/show/2145-19 [in Ukrainian].

2. Pro osnovni zasady rozvytku informatsiinoho suspilstva v Ukraini na 2007-2015 roky: Zakon Ukrainy vid 09.01.2007 roku № 537-V [About the basic principles of кого рівня самодисципліни лікаря-інтерна, проте як інтегрований курс дозволяє виявити та сформувати групу ризику на підставі аналізу даних середньої кількості пропущених претестувань та середнього відсотка успішності, особливо на етапі заочної форми інтернатури.

пу : http://www.meduniv.lviv.ua/index.php?option=com_co ntent\&view=article\&id=101\&Itemid=133\&lang=uk

6. Антонченко М. О. Організація дистанційного навчання в системі післядипломної педагогічної освіти [Електронний ресурс] / М. О. Антонченко // Педагогічні науки: теорія, історія, інноваційні технології. - 2014. № 1 (35). - Режим доступу : https://scholar.google.com.ua/ scholar?rlz=1C1AOHY_ruUA751UA752\&um=1\&ie=UTF8\&lr\&q=related:CTPO61tk5J55IM:scholar.google.com.

7. Роль інтернет-технологій у післядипломній підготовці лікарів-інтернів педіатрів на базах стажування [Електронний ресурс] / Л. В. Васильченко, Н. Л. Мерікова, Н. Ю. Горностаєва [та ін.] // Медична освіта. - 2016. № 1. - C. 8-10. - Режим доступу : https:// scholar.google.com.ua/scholar?rlz=1C1AOHY ruUA751UA752\&um=1\&ie=UTF-8\&lr\&q=related:3klIX n3SHFX2kM:scholar.google.com.

the information society development in Ukraine for 20072015: Law of Ukraine dated January 9, 2007 No. 537-V]. Retrieved from: http://zakon5.rada.gov.ua/laws/show/53716 [in Ukrainian].

3. Polozhennia pro dystantsine navchannia (Zatverdzheno nakazom Ministerstva osvity i nauky Ukrainy vid 25.04.2013 roku № 466) [Regulations on distance learning 
(Approved by the order of the Ministry of Education and Science of Ukraine dated April 25, 2013, No. 466)]. Retrieved from: http://zakon4.rada.gov.ua/laws/show/z070313\#n18 [in Ukrainian].

4. Hotuiemos do ispytu / Tsentr testuvannia pry MOZ Ukrainy [Preparing for the exam / Testing Center at the Ministry of Health of Ukraine]. Retrieved from: https:// www.testcentr.org.ua/uk/ispyty/dokumenty-i-materialy/ ekzamenatsiini-buklety [in Ukrainian].

5. Fakultet pisliadyplomnoi osvity LNMU imeni Danyla Halytskoho [Faculty of Postgraduate Education of Danylo Halytsky LNMU]. Retrieved from: http://www.meduniv. lviv.ua/index.php?option=com_content\&view=article\&id $=101 \&$ Itemid=133\&lang=uk [in Ukrainian].

6. Antonchenko, M.O. (2014). Orhanizatsiia dystantsiinoho navchannia v systemi pisliadyplomnoi pedahohichnoi osvi- ty [Organization of distance learning in the system of postgraduate pedagogical education]. Pedahohichni nauky: teoriia, istoriia, innovatsiini tekhnolohii - Pedagogical sciences : theory, history, innovative technologies, 1 (35) Retrieved rom: https://scholar.google.com.ua/scholar?rlz=1C1AOHY ruUA751UA752\&um=1\&ie=UTF-8\&lr\&q=related:CTPO 61tk5J55IM:scholar.google.com [in Ukrainian].

7. Vasylchenko,L.V., Merikova, N.L., \&Hornostayeva, N.Yu. (2016). Rol internet-tekhnolohii u pisliadyplomnii pidhotovtsi likariv-interniv pediatriv na bazakh stazhuvannia [The role of Internet technologies in postgraduate training of pediatricians interns at internship bases]. Medychna osvita - Medical Education, 1, 8-10 Retrieved from: https://scholar.google.com.ua/scholar?rlz=1C1AOHY ruUA751UA752\&um=1\&ie=UTF-8\&lr\&q=related:3klIX n3SHFX2kM:scholar.google.com [in Ukrainian].

Електронна адреса для листування: lida.minko@gmail.com 